\title{
Surgical Management of Solid Pseudopapillary Neoplasm of Pancreas- An Experience from Tertiary Care Centre
}

\section{Rohit Bhatta \\ Post Graduate Institute of Medical Education and Research}

\section{Santosh Irrinki}

Post Graduate Institute of Medical Education and Research

\section{Vikas Gupta}

Post Graduate Institute of Medical Education and Research

\section{Thakur Deen Yadav}

Post Graduate Institute of Medical Education and Research

\section{Yashwant Raj Sakaray}

Post Graduate Institute of Medical Education and Research

\section{Hemanth Kumar}

Post Graduate Institute of Medical Education and Research

\section{Ritambhra Nada}

Post Graduate Institute of Medical Education and Research

\section{Harjeet Singh ( $\sim$ harjeetsingh1982@gmail.com ) \\ PGIMER Chandiagrh https://orcid.org/0000-0002-0748-9473}

\section{Research Article}

Keywords: pancreaticoduodenectomy, distal pancreatectomy, SPN, pancreatic cancer, outcome

Posted Date: August 3rd, 2021

DOI: https://doi.org/10.21203/rs.3.rs-760309/v1

License: (c) (i) This work is licensed under a Creative Commons Attribution 4.0 International License. Read Full License 


\section{Abstract}

\section{Background:}

Solid Pseudopapillary neoplasm (SPN) is uncommon and constitutes to $1-2 \%$ of pancreatic tumors. Owing to its rarity, literature is spare on its clinicopathological characteristics and surgical outcomes.

\section{Methods}

Our study is a retrospective analysis of prospectively maintained data of patients with histologically proven SPN between January,2012 and December,2019. Patients Demography, clinical presentation, preoperative imaging, operative details, perioperative outcomes and long term follow up were recorded and analyzed.

\section{Results}

A total of 14 patients were included in the study, all were females with a median age of 19.5 years (range 15 - 35 years). All presented with pain abdomen. Eight (57.1\%) out of 14 patients were correctly diagnosed with Contrast enhanced computed tomography (CECT) abdomen. CECT revealed sloid cystic well encapsulated lesions in $12(85.7 \%)$ and homogenous mass lesions without cystic changes in 2(14.2\%) patients. The most common tumor location was Head/uncinate process (57.1\%). Eight (57.1\%) underwent pancreaticoduodenectomy and 6 (42.8\%) had undergone distal pancreatectomy. The mean size of tumour was $9.5 \mathrm{~cm}(2.8-14 \mathrm{~cm})$. The median postoperative stay was 9 days(range $4-20$ days). Seven patients (50\%) developed post-operative pancreatic fistula (Grade-A-6/7,Grade-B-1/7) and delayed gastric emptying (DGE) were noted in two (14.2\%).R0 resection could be achieved in 13 patients (92.8\%). Median follow up period was 49.5 months. One patient had postoperative recurrence after 48 months of surgery.

\section{Conclusion}

SPN is a rare tumor of pancreas. Lack of preoperative predictors for malignant potential complete oncological resections is essential for potential cure.

\section{Introduction}

Solid pseudopapillary neoplasm (SPN) is an uncommon tumour of pancreas. First described in 1959 by Virginia Frantz as "papillary cystic tumor of the pancreas". ${ }^{1}$ SPN was accepted as a separate clinicopathological entity after its ultrastructural features were described by Hamoudi et al and was subsequently included in WHO classification of pancreatic tumors as "solid pseudopapillary neoplasm" of pancreas in $19966^{2,3}$

SPEN comprises to only about 1 to $2 \%$ of pancreatic tumours. ${ }^{4-6}$ Young females in second or third decade of life represent more than $80 \%$ cases in published literature ${ }^{5-8}$ Because of its slow growth, patients remain asymptomatic until it attains large size and eventually present with pain abdomen with or without a palpable lump. ${ }^{4,5,9}$ The incidence has increased in recent past due to improved imaging techniques and better recognition of this disease. ${ }^{10,11}$ The surgical resection is the only curative modality of treatment in majority of patients with improved survival. ${ }^{7,8}$

Owing to rarity of the disease, there is limited literature on its pathogenesis, malignant potential, surgical strategy and its outcome. The aim of this study is to examine clinic-pathological characteristics, surgical approach and its outcome.

\section{Patients And Methods}

This study is a retrospective analysis of prospectively maintained database. Prior ethical approval was taken from institute ethical committee. Patients of histologically proven SPN who were operated between January 2012 and December 2019 were included in the study. Patient's demographic, clinical presentation, radiological data, laboratory parameters, operative 
details ,postoperative complications, outcome of surgery and follow up were recorded and analysed. The case records were retrieved for missing information. Patients with incomplete detail were excluded. All patients under went cross-sectional imaging [Contrast enhanced computed tomography (CECT) or magnetic resonance(MR) abdomen]. Endoscopic Ultrasound( EUS) was performed when there was a diagnostic uncertainty. The surgical approach was defined by the location of tumour and local invasion. The post-operative pancreatic fistula and delayed gastric emptying were defined as per international study group on pancreatic surgery. ${ }^{12,13}$ The perioperative mortality is defined as mortality within thirty days of surgery.

\section{Results}

\section{Clinical presentation}

A total of 14 patients with pathologically confirmed diagnosis of SPN were included in analysis.( Table1) The demography and clinical characteristics are shown in table 2. All the patients were females with median age of presentation 19.5 years ( range 15 to 35 years). All patients presented with symptom of pain abdomen and palpable lump was present in 6 (43\%). Tumor markers (CA 19-9 and CEA) were done in eight patents and showed a normal value.

\section{Radiological features}

All patients underwent CECT abdomen and 8(57.1\%) patients were correctly diagnosed based on CECT abdomen. Contrast enhanced magnetic resonance (CEMRI) abdomen was done in 2(14.2\%) patients, while endoscopic ultrasound (EUS) was done in six (42.8\%). Four out of six patients additionally required EUS guided fine needle aspiration. CECT abdomen showed heterogenous solid-cystic well encapsulated mass in 12(85.7\%) cases (figure 1) and solid homogenous mass lesion without cystic changes in two patients. Calcification was noted in only one. Most common location of mass was head/uncinate process of the pancreas $8(57.1 \%)$. The median size of the tumor was $9.5 \mathrm{~cm}$ ( range 2.8 to $14 \mathrm{~cm}$ ).

\section{Operative detail}

Eight patients underwent pancreaticoduodenectomy and one patient additionally required portal vein (PV) resection for local invasion. Three patients underwent spleen preserving distal pancreatectomy and three required distal pancreatectomy with splenectomy for distal pancreatic lesions. The median operative time for pancreaticoduodenectomy and distal pancreatectomy was 337 minutes (range 300 to 420 minutes) and 165 minutes (range 150 to 180 minutes) respectively. Intraoperative texture of remnant pancreas was soft and pancreatic duct was undilated $(<3 \mathrm{~mm})$ in all patients. Pancreaticojejunostomy (PJ) was performed using Duct to mucosa and Duking techniques in 4 patients each after pancreaticoduodenectomy. Pancreatic stump was closed with suture or GIA stapler after distal pancreatectomy.

\section{Post-operative course}

The median post-operative hospital stay was 9 days ( range 4-20 days). Six patients developed grade A and one patient developed grade B post-operative pancreatic fistula (POPF) respectively. Two patients had grade A delayed gastric emptying (DGE). Two patients had surgical site infections. There was no perioperative mortality.

\section{Histopathology}

Gross tumor morphology was solid mass with cystic changes (figure 2) in 12 out of 14 cases and two lesions were purely solid without any cystic changes. R0 resection was achieved in 13 patients and one patients had R1 resection due to margin positivity at pancreatic neck margin after pancreaticoduodenectomy. One patient who underwent PD with portal vein resection had portal vein invasion by tumor on histopathology. None of the patients had histological involvement of lymph nodes.

\section{Follow up}


Median follow up period was 49.5 months (range -18 -103 months). One patient developed local recurrence after 48 months after surgery and died after 9 months from the diagnosis of recurrence. Patient with R1 resection was recurrence free till the last follow up of 42 months.

\section{Discussion}

In this series we report the clinic-pathological and surgical outcome of rare pancreatic solid pseudopapillary neoplasm. All patients underwent regional pancreatectomy and only one out of 14 patient developed recurrence who later succumbed to disease progression. The management of remnant pancreatic stump, especially after pancreaticoduodenectomy was difficulty management due to its soft texture and undilated duct. In our series majority of patient had acceptable postoperative morbidity and there was no perioperative mortality.

Given its rarity and lack of unique identity, in the past it has also been misdiagnosed as adenocarcinoma, islet cell tumor, cystadenoma, papillary cystadenocarcinoma, or cystadenocarcinoma. ${ }^{8}$ Until its identity was standardized by WHO in 1996, it was described by a variety of names, like papillary epithelial neoplasm, solid and cystic acinar cell tumor, papillary cystic neoplasm, papillary cystic carcinoma, solid \& cystic tumor, low-grade papillary tumor, and Frantz's tumor. WHO classified this tumor into low grade malignant neoplasm. ${ }^{14,15}$ Still there are no accurate criteria to define malignant behaviors in these tumors. Many studies used the arbitrary criteria to predict malignancy, that includes tumor size $>5 \mathrm{~cm}$, vessels invasion, incomplete capsule and pancreatic duct involvement but none of these are accurate predictors. ${ }^{16,17}$

SPN is a disease of young female and rare in males. ${ }^{5,18}$ The median age of the presentation is 28.5 years. ${ }^{10}$ In our series the presentation was at an young age ( 19.5 years) and all patients were female. The most common presenting symptom in our series was pain abdomen followed by lump. The most common reported symptoms in literature is pain abdomen or discomfort, which was reported in $63 \%$ to $81 \%$ of patients. ${ }^{5,10}$ Due to improved imaging techniques and awareness of the disease the incidental diagnosis of the SPN has been reported in $9-39 . \%$ of patients. ${ }^{5,6,8,19-21}$ The less commonly reported symptoms being palpable lump, nausea, vomiting and weight loss. Rarely these tumours may presents with Jaundice and pancreatitis. $^{10}$

Routine laboratory parameters or tumor markers are of no help for the diagnosis of SPN. ${ }^{4}$ Although the imaging findings of SPN are not specific they are highly suggestive in appropriate clinical setting. ${ }^{21} \mathrm{CECT}$ being the most common imaging modality used, the second most common modality is transabdominal USG, followed by MRI and EUS. ${ }^{10}$ Cross sectional images usually show a large well-circumscribed, heterogeneous mass with varying solid and cystic components, generally demarcated by a peripheral capsule and occasional calcification. ${ }^{4} \mathrm{~A}$ retrospective imaging-pathological correlation study concluded that a large well encapsulated mass that demonstrate calcification and regions of haemorrhagic degeneration in a young woman is virtually diagnostic of SPN. ${ }^{21} \mathrm{MRI}$ is superior to CT in distinguishing certain tissue characteristics, such as haemorrhage, cystic degeneration or the presence of a capsule and may suggest correct diagnosis. ${ }^{21,22}$ There is no consensus on the utility of EUS/EUS-FNAC in the diagnosis of SPN. The reported diagnostic accuracy of EUS FNAC is from $56-81 \% .{ }^{23,24}$ A recent multicentric study reported the safety of EUS-FNAC and showed no impact of this procedure on long term recurrence of the disease. ${ }^{24}$ Though not necessary in every case, EUS FNAC procedure can be utilised in diagnostic dilemma especially in pancreatic head lesions. In the current study EUS was done in six patients and EUS-FNAC in four patients, three out of these four was confirmatory for SPN.

SPN is solitary tumor of pancreas, though multicentric and extra-pancreatic tumors have been reported in literature. ${ }^{25,26}$ Most common location in pancreas is the body and tail (59.3\%) followed by the head or uncinate process (36\%) and $1.1 \%$ were extra-pancreatic tumors. ${ }^{10}$ But in our study the most common location of tumor was head/uncinate of pancreas (57\%). Most SPN are large, sometime partially encapsulated mass with a mixture of solid and cystic component (foci of haemorrhage) in various proportions. ${ }^{6,8}$ However the gross appearance depends to some extent on the size of the tumor. While the smaller tumors tend to be homogenously solid, soft, less sharply circumscribed, tan to red mass with variable amounts of fibrosis; 
larger tumors commonly have a fibrous pseudo capsule surrounding the tumor usually demarcating it from the surrounding pancreatic parenchyma. ${ }^{9}$ Two out of 14 patients in our series had solid homogenous mass and these tumor were relatively small in size (largest diameter $-2.8 \mathrm{~cm}$ and $5.3 \mathrm{~cm}$ ).

Complete surgical excision is the standard of care for SPN. Surgery depends on the location of tumors, for pancreatic head lesion ,pancreaticoduodenectomy and for pancreatic body and tail lesion central or distal pancreatectomy with or without splenectomy is surgery of choice. The enucleation or parenchymal sparing resection for these tumors has been reported .But

this treatment strategy is associated with increased risk of resection margin positivity and post-operative recurrences. ${ }^{27}$ The reported incidence of lymph node metastasis is low (0.5\%- $2.2 \%)$, so routine lymphadenectomy is not recommended. ${ }^{10,28}$ With surgical resection SPN has very good prognosis, even for tumor with metastases or invasions. ${ }^{9,10}$ Local invasion, recurrence, or limited metastases are not contraindications for resection. ${ }^{9}$ In a recent systematic review and meta-analysis of predictors of recurrence, male gender, positive lymph node, R1 resection and LVI were associated with a statistically significant odds for recurrence. ${ }^{11}$ However many studies did no shows any significant relation of disease recurrence with male gender ,tumor size, R1 resection, local invasion ,and lymph node positivity. ${ }^{23,24,27}$ The Prognostic criteria's for disease behaviour is not well characterised in the literature. In our study one patient each with R1 resection and portal vein invasion had no disease recurrence and are alive. One patient who had no local invasion with R0 resection had disease recurrence 48 months after surgery.

In conclusion, solid pseudopapillary neoplasm of pancreas is a rare tumour with malignant potential. There is no definitive preoperative predictors for malignancy. Hence oncological resection should be performed for potential cure.

\section{Declarations}

Funding - No funding taken from any agency or organisation

Conflict of interest/ Competing interest - None

Availability of data and material - Available

Code availability - NA

Ethical approval - Taken from institute ethical committee

Consent to participate - NA

Consent for publication- NA

\section{References}

1. Frantz VK. Papillary tumors of the pancreas: benign or malignant tumors of the pancreas. In: Atlas of tumor pathology, Fascicles 27 and 28. Washington, DC, USA: Armed Forces Institute of Pathology, 1959. p. 32e3.

2. Kloppel G, Solcia E, Longnecker DS, Capella C, Sobin LH. Histological typing of tumours of the exocrine pancreas: World Health Organization international histological classification of tumours. 2nd ed. New York: Springer-Verlag, 1996.

3. Hamoudi AB, Misugi K, Grosfeld JL, Reiner CB. Papillary epithelial neoplasm of pancreas in a child. Report of a case with electron microscopy. Cancer 1970,26:1126-34

4. Vassos N, Agaimy A, Klein P et al. Solid-pseudopapillary neoplasm (SPN) of the pancreas: case series and literature review on an enigmatic entity. Int J Clin Exp Pathol 2013,6:1051-59

5. Reddy S, Cameron JL, Scudiere J, et al. Surgical management of solid-pseudopapillary neoplasms of the pancreas (Franz or Hamoudi tumors): a large single-institutional series. J Am Coll Surg. 2009,208:950-59

Page 5/10 
6. Song H, Dong M, Zhou J et al. Solid Pseudopapillary Neoplasm of the Pancreas: Clinicopathologic Feature, Risk Factors of Malignancy, and Survival Analysis of 53 Cases from a Single Center. Biomed Res Int. 2017,2017:5465261.

7. Tang LH, Aydin H, Brennan MF et al. Clinically aggressive solid pseudopapillary tumor of pancreas: A report of cases with components of undifferentiated carcinoma and a comparative clinicopathologic analysis of 34 conventional cases. Am J Surg Pathol 2005, 29:51-2.

8. Martin RC, Klimstra DS, Brennan MF et al. Solid-pseudopapillary tumor of pancreas: A surgical enigma? Ann Surg Oncol 2002, 9: 35-40.

9. Papavramidis T, Papavramidis S. Solid pseudopapillary tumors of the pancreas: review of 718 patients reported in english literature. J Am Coll Surg. 2005,200:965-72

10. Law J K, Ahmed A, Singh V K et al. A systematic review of solid-pseudopapillary neoplasms: are these rare lesions? Pancreas 2014, 43:331-37.

11. PP Yepuri N, Naous R, Meier AH, et al. A systematic review and meta-analysis of predictors of recurrence in patients with Solid Pseudopapillary Tumors of the Pancreas. HPB (Oxford). 2020,22:12-19.

12. Bassi C, Dervenis C, Butturini G,et al. Postoperative pancreatic fistula: an international study group (ISGPF) definition. Surgery. 2005,138:8-13.

13. Wente MN, Veit JA, Bassi C, et al. Postpancreatectomy hemorrhage (PPH) - an international study group of pancreatic surgery (ISGPS) definition. Surgery. 2007,142:20-25.

14. Kloppel G., Luttges J, Klimstra DS, et al. Solid- pseudopapillary neoplasm. In: Hamilton SR, Aaltonene LA, eds. World Health Organization Classification of Tumors: Pathology and Genetics of Tumors of the Digestive system. Lyon, france: IARC Press, 2000, 436:473-80.

15. Solcia E, Capella C, Kloppel G. Tumors of the pancreas. In: Atlas of Tumor Pathology, 3rd series, Fascicle 20. Washington, DC, USA: Armed Forces Institute of Pathology, 1997:120-30.

16. Kim MJ, Choi DW, Choi SH, et al. Surgical treatment of solid pseudopapillary neoplasms of the pancreas and risk factors for malignancy. Br J Surg 2014,101:1266e71.

17. Lee SE, Jang J, Hwang DW, Park K, Kim S. Clinical Features and Outcome of Solid Pseudopapillary Neoplasm: Differences Between Adults and Children. Arch Surg. 2008,143:1218-21

18. Aso A, Ihara E, Nakamura K et al. Solid pseudopapillary neoplasm of the pancreas in young male patients: three case reports. Case Rep Gastrointest Med. 2017,2017:9071678.

19. Estrella JS, Li L, Rashid A, et al. Solid pseudopapillary neoplasm of the pancreas: clinicopathologic and survival analyses of 64 cases from a single institution. Am J Surg Pathol. 2014,38:147-157.

20. Nguyen NQ, Johns AL, Gill AJ, et al. Clinical and immunohistochemical features of 34 solid pseudopapillary tumors of the pancreas. J Gastroenterol Hepatol. 2011,26:267-274.

21. Buetow PC, Buck JL, Pantongrag-Brown $L$ et al. Solid and papillary epithelial neoplasm of the pancreas: imagingpathologic correlation on 56 cases. Radiology. 1996,199:707-711.

22. Cantisani V, Mortele KJ, Levy A et al. MR imaging features of solid pseudopapillary tumor of the pancreas in adult and pediatric patients. Am J Roentgenol 2003, 181: 395- 401.

23. Butte JM, Brennan MF, Gönen M et al. Solid pseudopapillary tumors of the pancreas. Clinical features, surgical outcomes, and long-term survival in 45 consecutive patients from a single center. J Gastrointest Surg. 2011,15:350-357.

24. Karsenti D, Caillol F, Chaput U et al. Safety of Endoscopic Ultrasound-Guided Fine-Needle Aspiration for Pancreatic Solid Pseudopapillary Neoplasm Before Surgical Resection: A European Multicenter Registry-Based Study on 149 Patients. Pancreas. 2020,49:34-38.

25. Yamaguchi M, Fukuda T, Nakahara M, et al. Multicentric solid pseudopapillary neoplasms of the pancreas diagnosed by endoscopic ultrasound-guided fine needle aspiration: a case report. Surg Case Rep. 2015,1:110. 
26. Guo X, Li N, Ren K et al. Extrapancreatic solid pseudopapillary tumors: A clinicopathological analysis of two cases. Mol Clin Oncol. 2016,4:845-850.

27. Tjaden $\mathrm{C}$, Hassenpflug $\mathrm{M}$, Hinz $\mathrm{U}$ et al. Outcome and prognosis after pancreatectomy in patients with solid pseudopapillary neoplasms. Pancreatology. 2019,19:699-709

28. Yu PF, Hu ZH, Wang XB, et al. Solid pseudopapillary tumor of the pancreas: a review of 553 cases in Chinese literature. World J Gastroenterol. 2010,16:1209- 1214.

\section{Tables}

Table 1- Clinical data of 14 patients with solid pseudopapillary tumor of pancreas 


\begin{tabular}{|c|c|c|c|c|c|c|c|c|}
\hline \multirow{2}{*}{$\begin{array}{l}\text { S } \\
\text { no }\end{array}$} & \multirow{2}{*}{$\begin{array}{l}\text { Age } \\
\text { (Years) }\end{array}$} & \multirow{2}{*}{$\begin{array}{l}\text { Clinical } \\
\text { presentation }\end{array}$} & \multicolumn{2}{|l|}{ Tumor } & \multirow[t]{2}{*}{ Surgery } & \multirow{2}{*}{$\begin{array}{l}\text { Post- } \\
\text { operative } \\
\text { Complication }\end{array}$} & \multirow{2}{*}{$\begin{array}{l}\text { Follow } \\
\text { up } \\
\text { period } \\
\text { (Months) }\end{array}$} & \multirow{2}{*}{$\begin{array}{l}\text { Recurrence } \\
\text { or } \\
\text { metastasis }\end{array}$} \\
\hline & & & $\begin{array}{l}\text { Size } \\
(\mathrm{cm})\end{array}$ & Site & & & & \\
\hline 1 & 17 & $\begin{array}{l}\text { Pain abdomen, } \\
\text { Lump abdomen } \\
\text {,Nausea/vomiting, } \\
\text { early satiety }\end{array}$ & $12 \times 10$ & $\begin{array}{l}\text { Body \& } \\
\text { tail }\end{array}$ & $\begin{array}{l}\text { Spleen } \\
\text { preserving } \\
\text { distal } \\
\text { pancreatectomy }\end{array}$ & No & 21 & No \\
\hline 2 & 20 & Pain abdomen & $5 \times 5$ & $\begin{array}{l}\text { Head \& } \\
\text { neck }\end{array}$ & $\begin{array}{l}\text { Pancreato- } \\
\text { duodenectomy }\end{array}$ & $\begin{array}{l}\text { DGE grade A, } \\
\text { POPF grade } \\
\text { B }\end{array}$ & 24 & No \\
\hline 3 & 19 & $\begin{array}{l}\text { Pain abdomen, } \\
\text { lump, early satiety }\end{array}$ & $10 \times 8$ & $\begin{array}{l}\text { Head \& } \\
\text { uncinate }\end{array}$ & $\begin{array}{l}\text { Pancreato- } \\
\text { duodenectomy }\end{array}$ & No & 18 & No \\
\hline 4 & 32 & Pain abdomen & $8 \times 8$ & $\begin{array}{l}\text { Distal } \\
\text { body }\end{array}$ & $\begin{array}{l}\text { Spleen } \\
\text { preserving } \\
\text { distal } \\
\text { pancreatectomy }\end{array}$ & $\begin{array}{l}\text { POPF grade } \\
\text { A }\end{array}$ & 39 & No \\
\hline 5 & 32 & $\begin{array}{l}\text { Pain abdomen, } \\
\text { Nausea/vomiting }\end{array}$ & $8 \times 8$ & $\begin{array}{l}\text { Body \& } \\
\text { tail }\end{array}$ & $\begin{array}{l}\text { Distal } \\
\text { pancreatectomy } \\
\text { + splenectomy }\end{array}$ & $\begin{array}{l}\text { POPF grade } \\
\text { A }\end{array}$ & 21 & No \\
\hline 6 & 27 & Pain abdomen & $6 \times 6$ & Tail & $\begin{array}{l}\text { Lap to open } \\
\text { Distal } \\
\text { pancreatectomy } \\
\text { + splenectomy }\end{array}$ & $\begin{array}{l}\text { POPF grade } \\
\text { A }\end{array}$ & 62 & No \\
\hline 7 & 35 & Pain abdomen & $\begin{array}{l}4.5 x \\
3\end{array}$ & Head & $\begin{array}{l}\text { Pancreato- } \\
\text { duodenectomy }\end{array}$ & $\begin{array}{l}\text { POPF grade } \\
\text { A }\end{array}$ & 74 & No \\
\hline 8 & 18 & $\begin{array}{l}\text { Pain abdomen, } \\
\text { lump abdomen }\end{array}$ & $10 \times 10$ & Head & $\begin{array}{l}\text { Pancreato- } \\
\text { duodenectomy }\end{array}$ & No & 90 & No \\
\hline 9 & 17 & Pain abdomen & $7 \times 6$ & Head & $\begin{array}{l}\text { Distal } \\
\text { pancreatectomy } \\
\text { + splenectomy }\end{array}$ & $\begin{array}{l}\text { POPF grade } \\
\text { A } \\
\text { Deep SSI }\end{array}$ & 67 & No \\
\hline 10 & 22 & $\begin{array}{l}\text { Pain abdomen, } \\
\text { lump abdomen }\end{array}$ & $12 \times 12$ & Head & $\begin{array}{l}\text { Pancreato- } \\
\text { duodenectomy } \\
\text { with portal vein } \\
\text { resection (type } \\
\text { III) }\end{array}$ & No & 42 & No \\
\hline 11 & 18 & $\begin{array}{l}\text { Pain abdomen, } \\
\text { lump abdomen }\end{array}$ & $14 \times 12$ & Head & $\begin{array}{l}\text { Pancreato- } \\
\text { duodenectomy }\end{array}$ & No & 57 & $\begin{array}{l}\text { Yes } \\
\text { Died of } \\
\text { recurrence }\end{array}$ \\
\hline 12 & 15 & Pain abdomen & $10 \times 10$ & $\begin{array}{l}\text { Body \& } \\
\text { tail }\end{array}$ & $\begin{array}{l}\text { Spleen } \\
\text { preserving } \\
\text { distal } \\
\text { pancreatectomy } \\
+ \\
\text { cholecystectomy }\end{array}$ & No & 72 & No \\
\hline 13 & 29 & $\begin{array}{l}\text { Pain abdomen, } \\
\text { lump, } \\
\text { Nausea/vomiting }\end{array}$ & $9 \times 7$ & $\begin{array}{l}\text { Head \& } \\
\text { uncinate }\end{array}$ & $\begin{array}{l}\text { Pancreato- } \\
\text { duodenectomy }\end{array}$ & $\begin{array}{l}\text { POPF grade } \\
\text { A } \\
\text { Deep SSI }\end{array}$ & 103 & No \\
\hline 14 & 19 & $\begin{array}{l}\text { Pain abdomen, } \\
\text { Nausea/vomiting }\end{array}$ & $10 \times 8$ & Head & $\begin{array}{l}\text { Pancreato- } \\
\text { duodenectomy }\end{array}$ & No & 18 & No \\
\hline
\end{tabular}


Table 2- Showing demographic, clinical and operative detail

\begin{tabular}{|ll|}
\hline Parameter & Number (\%) \\
\hline Age, median (Range) Years & $19.5(15-35)$ \\
\hline Clinical presentation, $n(\%)$ & $14(100 \%)$ \\
\hline Pain abdomen & $06(42.8 \%)$ \\
Palpable lump abdomen & $04(28.6 \%)$ \\
Nausea vomiting & $02(14.2 \%)$ \\
Early satiety & $04(28.6 \%)$ \\
Loss of weight & 0 \\
\hline Incidental detection & \\
\hline Tumor location $n$ (\%) & $8(57.1 \%)$ \\
\hline Head/Uncinate & $1(7.1 \%)$ \\
Body & $3(21.4 \%)$ \\
Both body \& tail & $1(7.1 \%)$ \\
\hline Tail & $9.5(4.5-14)$ \\
\hline Tumor size, Median (Range) cm & $3(21.4 \%)$ \\
\hline Surgery & $7(50 \%)$ \\
\hline Pancreato-duodenectomy & $1(7.1 \%)$ \\
\hline Pancreato-duodenectomy + portal vein resection & $3(21.4 \%)$ \\
\hline Spleen preserving distal pancreatectomy & $3(20)$ \\
\hline Post-operative hospital stays, median (Range) days & \\
\hline
\end{tabular}

\section{Figures}

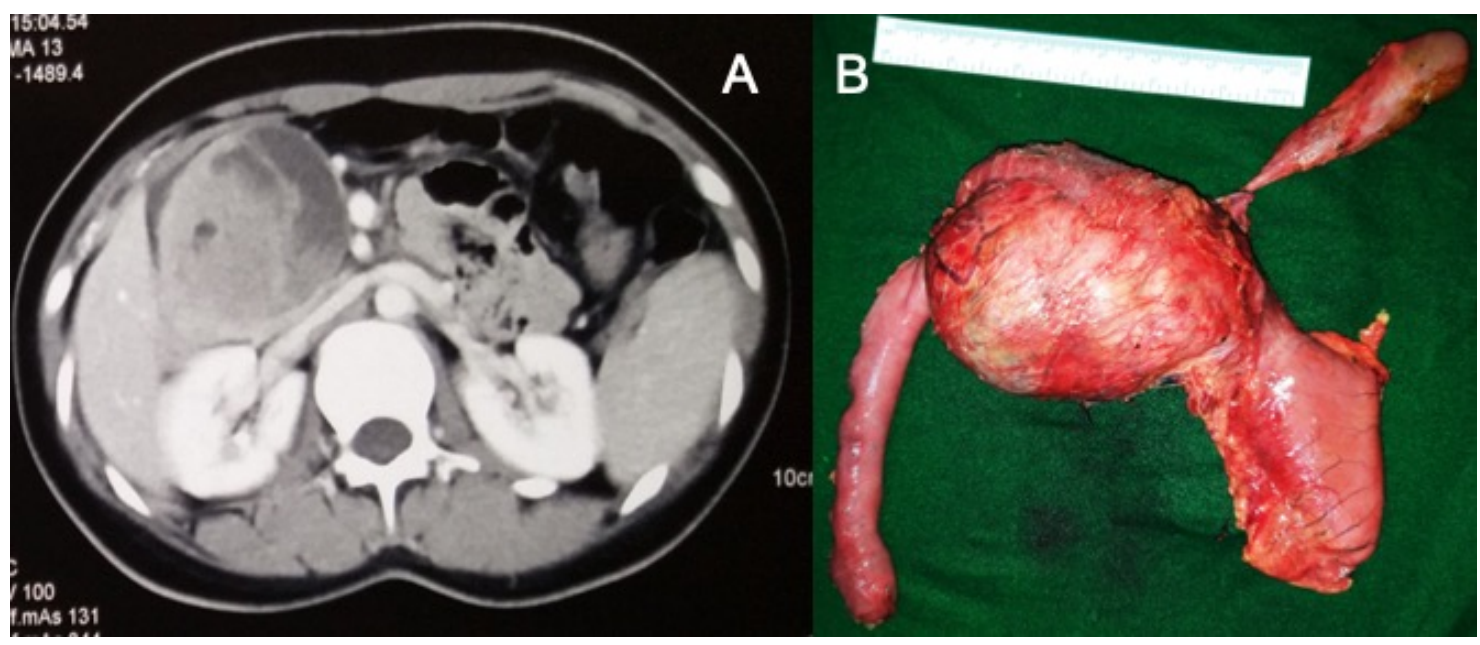




\section{Figure 1}

A-Contrast enhanced computed tomography showing well encapsulated solid cystic lesion with peripheral rim of solid component involving the head of pancreas. B- Resected pancreaticoduodenectomy specimen of same patient showing large tumor involving pancreatic head
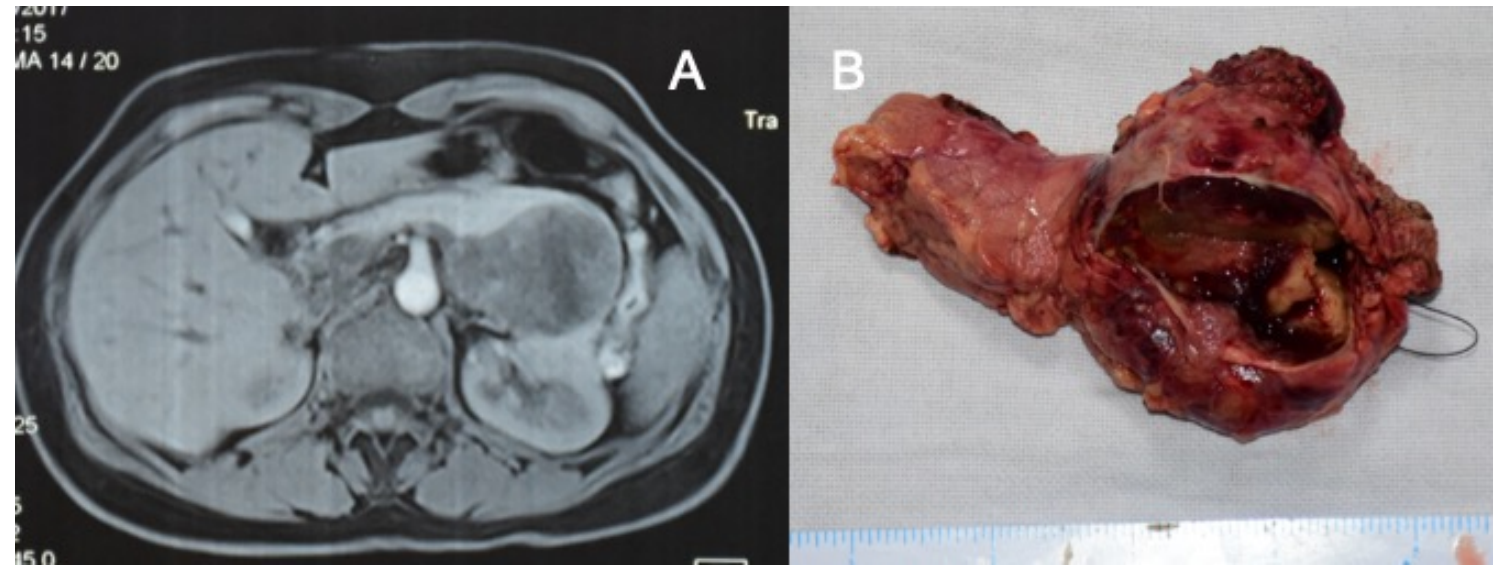

\section{Figure 2}

A- Magnetic resonance imaging (MRI) -T1weighted image shows well defined, encapsulated solid and cystic mass with haemorrhagic degeneration in the distal pancreas. B- Resected (distal pancreatectomy) cut open specimen of the same patients showing well encapsulated solid pseudopapillary neoplasm with cystic degeneration. 